\title{
Retraction Note to: Overexpression of A613T and G462T variants of DNA polymerase $\beta$ weakens chemotherapy sensitivity in esophageal cancer cell lines
}

Yuanyuan Wang ${ }^{1+}$, Xiaonan Chen ${ }^{1 \dagger}$, Qianqian Sun ${ }^{1}$, Wenqiao Zang ${ }^{1}$, Min $\mathrm{Li}^{1}$, Ziming Dong ${ }^{1,2}$ and Guoqiang Zhao ${ }^{1,2^{*}}$

\section{Retraction to: Cancer Cell Int (2016) 16:85 \\ https://doi.org/10.1186/s12935-016-0362-x}

The Editor-in-Chief has retracted this article [1] because Figure $6 \mathrm{a}$ and $6 \mathrm{~b}$ show overlap with Figure $4 \mathrm{~b}$ in [2]. An investigation by Zhengzhou University has confirmed that these figures overlap. The data reported in this article are therefore unreliable.

Guoqiang Zhao agrees with this retraction. Yuanyuan Wang, Xiaonan Chen, Qianqian Sun, Wenqiao Zang, $\mathrm{Min} \mathrm{Li}$, and Ziming Dong have not responded to any correspondence about this retraction.
Received: 3 April 2019 Accepted: 3 April 2019

Published online: 08 April 2019

\section{References}

1. Wang Y, Chen X, Sun Q, Zang W, Li M, Dong D, Zhao G. Overexpression of A613T and G462T variants of DNA polymerase $\beta$ weakens chemotherapy sensitivity in esophageal cancer cell lines. Cancer Cell Int. 2016;16:85. https://doi.org/10.1186/s12935-016-0362-x.

2. Sun S, Feng L, Zhao G, Dong Z. HAX-1 promotes the chemoresistance, invasion, and tumorigenicity of esophageal squamous carcinoma cells. Dig Dis Sci. 2012;57:1838. https://doi.org/10.1007/s10620-012-2108-5.

\section{Author details}

1 School of Basic Medical Sciences, Zhengzhou University, No.100 Kexue Road, 450001 Zhengzhou, Henan, China. ${ }^{2}$ Collaborative Innovation Center of Cancer Chemoprevention of Henan, 450001 Zhengzhou, Henan, China.

The original article can be found online at https://doi.org/10.1186/s1293 5-016-0362-x.

\section{Publisher's Note}

Springer Nature remains neutral with regard to jurisdictional claims in published maps and institutional affiliations.

*Correspondence: zhaogq@zzu.edu.cn

†Yuanyuan Wang and Xiaonan Chen contributed equally to this work

1 School of Basic Medical Sciences, Zhengzhou University, No.100 Kexue

Road, 450001 Zhengzhou, Henan, China

Full list of author information is available at the end of the article 